\title{
Infection with Hepatitis $B$ and $C$ Virus in the Democratic Republic of Congo: A Public Health Problem
}

\author{
Ben Ilunga Bulanda1, Berry Ikolango Bongenya ${ }^{1}$, Jean-Yves Debels Kabasele1, \\ Médard Omakoy Okonda1, Divine Chuga ${ }^{1}$, Christian Tshisumbu' ${ }^{1}$, Elvis Tshunza Kateba1, \\ Erick Ntambwe Kamangu, ${ }^{1,2 *}$ \\ 1"HIV/AIDS Focus" Research Group, Kinshasa, Democratic Republic of Congo \\ ${ }^{2}$ Molecular Biochemistry Service, Department of Basic Sciences, Faculty of Medicine, University of Kinshasa (UNIKIN), \\ Kinshasa, Democratic Republic of Congo \\ Email: *erick.kamangu@unikin.ac.cd
}

How to cite this paper: Bulanda, B.I., Bongenya, B.I., Kabasele, J.-Y.D., Okonda, M.O., Chuga, D., Tshisumbu, C., Kateba, E.T. and Kamangu, E.N. (2018) Infection with Hepatitis B and C Virus in the Democratic Republic of Congo: A Public Health Problem. Open Access Library Journal, 5: e4760.

https://doi.org/10.4236/oalib.1104760

Received: July 6, 2018

Accepted: August 11, 2018

Published: August 14, 2018

Copyright (๑) 2018 by authors and Open Access Library Inc.

This work is licensed under the Creative Commons Attribution International License (CC BY 4.0).

http://creativecommons.org/licenses/by/4.0/

\begin{abstract}
Background: Viral hepatitis represents a major public health burden with more than 375 million people with chronic hepatitis B infection and 130 to 150 million with hepatitis C for 2016. Sub-Saharan Africa has the heaviest burden of the epidemic. Objective: The objective of this review is to present the characteristics of hepatitis $\mathrm{B}$ and $\mathrm{C}$ infections (HBV and HCV), present the synthesis and estimate its magnitude in the Democratic Republic of Congo for the last 20 years. Methods: This work consisted in cataloging the various published articles and abstracts presented in scientific conferences having as subject of interest the infection with viral hepatitis B and C in the DRC. The search for these published works on different infections was done on the internet from different search engines. The research was limited to published works and abstracts presented over the last 20 years. Pediatric studies, studies in patients with renal or hepatic infections or without original data were not included in this review. Results: According to the various works published and presented in conference since 1997, the populations targeted for the investigations on the hepatitis $B$ and $C$ infections are the poly-transfused, the blood donors and the People Living with HIV. Seven (7) works have been documented for the DRC meeting the various selection criteria. In 1999, the carriage of HBV infection was 9.2\% in Kinshasa. In 2000, the carriage of HBV was $5.9 \%$ while that of HCV was $4.8 \%$ in Kinshasa. In 2001, the portage of HCV was 5.0\% in Kinshasa. In 2004, the prevalence of HBs antigen was 5.4\% in Kisangani. In 2008, the prevalence of $\mathrm{HBV}$ and $\mathrm{HCV}$ was $8 \%$ and $4 \%$ respectively in Bukavu. In 2008, seroprevalences of HBV and HCV were re-
\end{abstract}


spectively $4.2 \%$ and $3.8 \%$ in Bukavu. In 2012 and 2013, prevalence of HCV was $5.8 \%$ and $5.2 \%$ respectively in Kinshasa. Conclusions: Although often asymptomatic, viral hepatitis $\mathrm{B}$ and $\mathrm{C}$ are a public health problem for the Democratic Republic of Congo. The prevalence of these viral infections is far superior to that of HIV infection in Blood Transfusion Centers across the country.

\section{Subject Areas}

Public Health

\section{Keywords}

Hepatitis B, Hepatitis C, Kinshasa

\section{Introduction}

Hepatitis $\mathrm{B}$ and $\mathrm{C}$ viruses ( $\mathrm{HBV}$ and $\mathrm{HCV}$ ) are different viruses that have the same modes of transmission, the same targets and present the same symptoms. $\mathrm{HBV}$ is a DNA virus belonging to the family of hepadnaviridae of the genus orthohepadnavirus [1]. In contrast, HCV is an RNA virus of the flaviridae family of the genus hepacivirus [1].

Viral hepatitis represents a major public health burden with more than 375 million people with chronic hepatitis $\mathrm{B}$ infection and 130 to 150 million with hepatitis C for 2016, of which 4 to 5 million infected with the Human Immunodeficiency Virus (HIV) and about one million deaths per year [1]. Sub-Saharan Africa bears the greatest burden of the epidemic.

For HBV, transmission is mainly parenteral, sexual and maternofetal [2] [3]. It is linked to parenteral injections (blood transfusions, intravenous drug use, hemodialysis), sex with people infected with the virus, transplacental transit or delivery (vertical transmission) [1] [2] [3] [4]. Immunocompetent adults have more than $90 \%$ spontaneous HBV clearance capacity. Likewise for HCV, transmission is mainly parenteral [1] [2] [3] [5].

People infected with HBV and HCV do not usually feel sick and recover completely. Those who are symptomatic have symptoms similar to the common flu (fever, headaches, etc.) as well as stomachaches, diarrhea and jaundice that normally begin 1 - 3 months after the virus enters the body. Ten percent (10\%) of adults with acute hepatitis $\mathrm{B}$ and $80 \%$ of those with hepatitis $\mathrm{C}$ develop chronic infection that may result in cirrhosis and/or liver cancer later in the patient [1].

For several years, different works have made it possible to better understand and specify the different profiles as well as the carriage of hepatitis infection in the Democratic Republic of Congo (DRC) among transfused persons, blood donors and People Living with HIV (PLHIV). The objective of this review is to present the characteristics of hepatitis $\mathrm{B}$ and $\mathrm{C}$ infections ( $\mathrm{HBV}$ and $\mathrm{HCV}$ ), to present the synthesis and to estimate the extent of this infection in the DRC for 
the last 20 years.

\section{Methods}

\subsection{Literature Search}

This work consisted in cataloging the various published articles and abstracts presented in scientific conferences having as subject of interest the viral hepatitis $\mathrm{B}$ and C infection in the Democratic Republic of Congo (DRC). The search for these published works on the different infections was made from the following search engines on the internet: 1) Cochrane library; 2) Google scholar; 3) MEDLINE/PubMed; 4) POPLINE electronic database of published scientific documents; 5) Public access data on conference papers; 6) Scientific report published on the internet. This online search was based on the following keywords: "HBV, HCV, DRC", "hepatitis, and Democratic Republic of Congo".

\subsection{Criteria for Inclusion and Non-Inclusion}

The research was limited to published works and abstracts presented over the last 20 years (1997 to 2017). The manuscripts were retained according to the relevance of the methodology of the different works, the results and the representability of the samples. The socio-demographic information of the sample, the methods of measurement and the objectives were considered in the evaluation of the articles. Re-reading of the various manuscripts excluded articles and abstracts that did not directly concern hepatitis B and C in the DRC. Pediatric studies, studies in patients with renal or hepatic infections or without original data were not included in this review.

\section{Results and Discussions}

The objective of this literature review was to present the carriage and extent of hepatitis B and C infection (HBV and HCV) in the Democratic Republic of Congo (DRC) compared to the different data published over the last 20 years. Seven (7) works have been documented for the DRC particularly meeting the different selection criteria. According to the various works published and presented in conference since 1997, the populations targeted for the surveillance surveys on the hepatitis B and C infections are the poly-transfused, the blood donors and the People Living with HIV (PLHIV). All data are presented in Table 1 .

In 1999, Mbendi NC et al. reported a prevalence of HBV infection of 9.2\% using 7277 sera from volunteers who agreed to donate blood for the first time (first time blood donor) in the eastern part of the city of Kinshasa [6]. The average age was $32.01 \pm 9.23$ years with extremes ranging from 10 to 79 years. The most represented age group in this cohort was 30 to 39 years, followed by 25 to 29 years. The male patients dominated in the total population of $77.9 \%$ [6]. This work was carried out in collaboration with the following hospitals: University Clinics of Kinshasa (UCK), Kingasani Hospital Center (CHK), Kinshasa 
Table 1. Prevalence of Hepatitis infections per studies in DRC.

\begin{tabular}{|c|c|c|c|c|c|c|}
\hline Study & Years & City & $\begin{array}{c}\text { Total } \\
\text { Number of } \\
\text { population }\end{array}$ & $\begin{array}{c}\text { Number of } \\
\text { females }\end{array}$ & $\begin{array}{c}\text { Prevalence } \\
\text { of } \mathrm{HBV}\end{array}$ & $\begin{array}{c}\text { Prevalence } \\
\text { of } \mathrm{HCV}\end{array}$ \\
\hline Mbendi NC et al. [6] & 1999 & Kinshasa & 7277 & $1608(22.1 \%)$ & $9.2 \%$ & - \\
\hline Baleka et al. [7] & 2000 & Kinshasa & 373 & $62(16.6 \%)$ & $5.9 \%$ & $4.8 \%$ \\
\hline Laurent C et al. [8] & 2001 & Kinshasa & 1806 & $1806(100 \%)$ & - & $5.0 \%$ \\
\hline Batina A et al. [9] & 2003-2004 & Kisangani & 3390 & $1843(54.4 \%)$ & $5.4 \%$ & - \\
\hline Kabinda JM et al. [10] & 2008 & Bukavu & $\begin{array}{l}211 \text { VIH- } \\
209 \mathrm{VIH}+\end{array}$ & $\begin{array}{l}142(67.2 \%) \\
141(67.4 \%)\end{array}$ & $\begin{array}{l}8 \% \\
8 \%\end{array}$ & $\begin{array}{c}4 \% \\
10 \%\end{array}$ \\
\hline Kabinda JM et al. [11] & 2012 & Bukavu & 1079 & $298(27.6 \%)$ & $4.2 \%$ & $3.88 \%$ \\
\hline $\begin{array}{c}\text { Kamangu NE et al. } \\
{[12]}\end{array}$ & $\begin{array}{l}2012 \\
2013\end{array}$ & Kinshasa & $\begin{array}{l}5271 \\
5040\end{array}$ & $1467(14.2 \%)$ & - & $\begin{array}{l}5.8 \% \\
5.2 \%\end{array}$ \\
\hline
\end{tabular}

Kimbanguist Hospital (HKK) and N'djili Hospital (HND) [6].

In 2000, Baleka F et al. worked on 373 blood donor sera from blood transfusion centers at Kinshasa General Hospital (KGH), Kimbanseke Kimbanguist Hospital, Kintambo Hospital, Bondeko Clinic and Ngaliema Clinic, all in the city of Kinshasa [7]. HBV carriage was $5.9 \%$ while HCV carriage was $4.8 \%$ in this donor population. The most represented age group is that of 21 to 39 years followed by that of 40 to 49 years for both viral infections [7]. Donors were predominantly male dominated with 311 donors (83.4\%). The median age of the population was 36 years old. The majority of donors (92.5\%) were family donors [7].

In 2001, Laurent $\mathrm{C}$ et al. presented a carriage of 5.0\% for HCV in an all-female population of $1806 \mathrm{HIV}$-negative patients [8]. The population consisted of professional sex workers followed in appropriate treatment centers and pregnant women followed in prenatal consultation structures accredited by the health system of Kinshasa [8].

In Kisangani, capital of Orientale Province, Batina A et al. published a portage of HBs antigen in the period from 2003 to 2004 of $5.4 \%$ in a population of 3390 blood donors at the Provincial Blood Transfusion Center (PBTC) of Kisangani [9]. The average age of donors was $35 \pm 1.24$ years, and females (54.4\%) dominated the donor population [9]. The majority (69.2\%) of blood donors were family donors followed by volunteer donors (29.2\%) [9].

In Bukavu, capital of South Kivu province, Kabinda JM et al. reported hepatitis $B$ and $C$ prevalences of $8 \%$ and $10 \%$ respectively in a population of 209 immunocompromised patients (HIV positive) and $8 \%$ and $4 \%$ in a population of 211 immunocompetent controls (HIV-negative) in 2008 [10]. The mean ages of the 2 populations were $36.7 \pm 11.7$ years and $37.3 \pm 11.3$ years, respectively, for immunocompromised and immunocompetent patients. The most represented age group was 21 to 39 years in both populations [10]. Females were more represented in both populations; $67.2 \%$ in the immunocompetent group and $67.4 \%$ in the immunocompromised group [10]. The immunocompetent group 
consisted of $143(67.8 \%)$ volunteer blood donors and 68 (32.2\%) patients hospitalized in the Internal Medicine Department of the Bukavu Provincial Hospital [10].

In 2014, Kabinda JM et al. published a seroprevalence of hepatitis B and C respectively of $4.2 \%$ and $3.8 \%$ on a population of 1079 voluntary unpaid blood donors in Bukavu [11]. The most represented age group was under 30 years in the range of 18 to 60 years and a median age of 26 years. The male sex $(72.4 \%)$ was dominant in the surveyed population [11]. Just over half, 54.5\%, consisted of new blood donors [11]. According to the study, for the city of Bukavu, the profile of the donor at risk is a married male blood donor from rural areas under the age of 30 years [11].

For the years 2012 and 2013, Kamangu NE et al. published a carriage of HCV respectively $5.8 \%$ and $5.2 \%$ of 5271 and 5040 blood bags tested at National Blood Transfusion Center (NBTC) in Kinshasa, a total of 10,311 blood bags for 2 years [12]. The most represented age group in the population was 18 - 30 years old with $82.6 \%$ followed by that of 31 - 40 years old with $13.5 \%$ and that of $41-50$ years old with $3.2 \%$ [12]. The male dominated the population with $85.8 \%$. Carriage of $\mathrm{HCV}$ was twice that of HIV infection under the same conditions [12].

Studies presenting the prevalence of hepatitis B and C in the DRC are for the most part conducted in Blood Transfusion Centers (BTC) across the country. There is no study conducted in the general population.

Through all these different studies, it is clear that the prevalence of hepatitis is always higher than that of HIV in blood donor populations; from $6.4 \%$ and $9.2 \%$ in 1999 [6] to $3.8 \%$ and $5.9 \%$ in 2000 [7] respectively for HIV and HBV, or $3.8 \%$ and $4.8 \%$ in 2000 [7] to $2.1 \%$ and $5.2 \%$ in 2013 [12] respectively for HIV and $\mathrm{HCV}$ specifically in Kinshasa. The prevalence of HBV is always higher than that of HCV in the same populations [7] [10] [11].

\section{Conclusion}

Although often asymptomatic, viral hepatitis B and C are a public health problem for the Democratic Republic of Congo. The carriage of these viral infections is far superior to that of HIV infection in Blood Transfusion Centers across the country.

\section{Conflict of Interest}

The authors declare that there is no conflict of interest.

\section{References}

[1] Laurain, A., Vallet-Pichard, A., Corouge, M. and Pol, S. (2016) Hépatites Virales. EMC-Maladies Infectieuses. 13, 2.

[2] Yombi, J.C., Marot, J.C., De Visscher, N., Ausselet, N., Vincent, A. and Vandercam, B. (2007) La co-infection par le Virus de l'Immunodéficience Humaine (VIH) et le Virus de l'Hépatite C (VHC) ou le Virus de l'Hépatite B (VHB). Louvain Médical, 
126, 238-245.

[3] Barth, R.E., Huijgen, Q., Taljaard, J. and Hoepelman, A.I.M. (2010) Hepatitis B/C and HIV in Sub-Saharan Africa: An Association between Highly Prevalent Infectious Diseases. A Systematic Review and Meta-Analysis. International Journal of Infectious Diseases, 14, e1024-e1031. https://doi.org/10.1016/j.ijid.2010.06.013

[4] Wright, T.L. and Lau, J.Y. (1993) Clinical Aspects of Hepatitis B Virus Infection. The Lancet, 342, 1340-1344. https://doi.org/10.1016/0140-6736(93)92250-W

[5] Seef, L.B., Buskell-Bales, Z., Wright, E.C., Durako, S.J., Alter, H.J. and Iber, F.L. (1992) Long-Term Mortality after Transfusion-Associated Non-A, Non-B Hepatitis. The National Heart, Lung, and Blood Institute Study Group, The New England Journal of Medicine, 332, 1906-1911. https://doi.org/10.1056/NEJM199212313272703

[6] Mbendi, N.C., Longo-Mbenza, B., Mbendi, N.S., Muyembe, J.J., Situakibanza, N.H. and Vangu, N.D. (2001) Prévalence du VIH et de l'Antigène HBs chez les receveurs de sang à Kinshasa-Est, République Démocratique du Congo. Médecine Tropicale, 61, 139-142.

[7] Baleka, F., Pukuta, E., Lay, Y., Mwema, G., Mumba, M. and Muyembe, T.J.J. (2014) Prévalence et co-infection de VIH, VHC et VHB chez les donneurs de sang à Kinshasa, RDC. Congo Sciences, 2, 37-40.

[8] Laurent, C., Henzel, D., Mulanga-Kabeya, C., Maertens, G., Larouze, B. and Delaporte, E. (2001) Seroepidemiological Survey of Hepatitis C Virus among Commercial Sex Workers and Pregnant Women in Kinshasa, Democratic Republic of Congo. International Journal of Epidemiology, 30, 872-877. https://doi.org/10.1093/ije/30.4.872

[9] Batina, A., Kabemba, S. and Malengela, R. (2007) Marqueurs infectieux chez les donneurs de sang en République Démocratique du Congo (RDC). Revue medicale de Bruxelles, 28, 145-149.

[10] Kabinda, J.M and Katchunga, B.P. (2010) Les Hépatites virales B et C chez les porteurs du Virus de l'Immunodépression Humaine à Bukavu (Sud-Kivu), République Démocratique du Congo. Journal Africain d Hépato-Gastroentérologie, 4, 230-235.

[11] Kabinda, J.M., Miyanga, S.A., Misingi, P. and Ramazani, S.Y. (2014) Les hépatites B et $\mathrm{C}$ chez les donneurs bénévoles de sang et non rémunérés de l'Est de la République Démocratique du Congo. Transfusion Clinique et Biologique, 21, 111-115. https://doi.org/10.1016/j.tracli.2014.04.001

[12] Kamangu, N.E., Nseka, K.N., Ndombasi, M.A. and Mvumbi, L.G. (2016) Séroprévalence de la coïnfection VIH-VHC chez les donneurs de sang au Centre National de Transfusion Sanguine à Kinshasa. Proceeding of 8 ème Conférence Internationale Francophone-AFRA VIH 2016, Bruxelles, 20-23 April 2006, 375. 